\title{
PENGARUH TOPOGRAFI DAN KESARANGAN BATUAN KARBONAT TERHADAP WARNA TANAH PADA JALUR BARON-WONOSARI KABUPATEN GUNUNGKIDUL, DIY
}

\author{
Djoko Mulyanto * dan Surono ** \\ * Jurusan Ilmu Tanah, Fakultas Pertanian, \\ Universitas Pembangunan Nasional "Veteran" Yogyakarta \\ E-mail: j.mulyanto@yahoo.com \\ ** Pusat Survei Geologi, Badan Geologi \\ E-mail: surono@grdc.esdm.go.id
}

\begin{abstract}
Western part of the East Jawa Southern Mountains, which is distributed from Parangtritis, Yogyakarta to Pacitan Bay is the Gunung-Sewu Hills. The carbonate rocks on the Baron-Wonosari transect has some litofacies, and the soils overlying the rocks show some color varieties. Topography of Baron-Wonosari transect can be divided into two areas: southern part (Baron-Mulo) and northern part (Mulo-Wonosari). The southern part is a billy land, whereas the northern part is a lowland plain. Soils on the southern part are dominated by red soils group, whereas on the northern part dominated by black soils group. The phenomenon is very interesting to be studied. The aim of research was to study relationship of soil colour with topography and pores of underlying carbonate rocks. Methods consist of landform especially topography observation, and soil colour by Munsell Soil Colour Chart, whereas laboratory analysis namely micro porosity and geochemical of carbonate rock. The results showed that micro pores of rocks have no effect to the soil colour formation. However, secondary pores (macro and mega) be suggested influent on red soil formation. Concentration of iron ( $\mathrm{Fe}$ ) and mangan $(\mathrm{Mn})$ elements of carbonate rock have no effect on the formation of soil colour. Topograpby and rock secondary porosity be estimated have a role as controlling factors on the formation of soil colour by leaching process mechanism. An area, which has a bigh leaching capacity tend to be found much of red soils, whereas an area which has a low leaching capacity will be formed black soils.
\end{abstract}

Keywords: carbonate rocks, leaching process, secondary pores, soil colour, topography

\section{PENDAHULUAN}

Kawasan Pegunungan Selatan bagian tengah, yang membentang luas berarah barat - timur mulai dari Parangtritis (Propinsi daerah Istimewa Yogyakarta) sampai dengan Teluk Pacitan (Propinsi Jawa Timur), oleh Husein dan Sriyono (2007) disebut sebagai Pegunungan Selatan
Jawa Timur bagian barat. Kawasan ini merupakan perbukitan yang sebagian besar dibentuk oleh batuan karbonat, yang membentuk morfologi karst Gunungsewu. Morfologi karst terdiri atas himpunan ratusan bukit kecil berbentuk kerucut yang puncaknya berbentuk tumpul. Bukit tumpul itu umumnya berdiameter 25-300 $\mathrm{m}$ dengan tinggi berkisar dari $30 \mathrm{~m}$ sampai 
$200 \mathrm{~m}$. Dolina, yang merupakan cekungan di antara perbukitan umumnya berbentuk bundar yang terisi tanah, dan seringkali juga terisi air sehingga menjadi danau. Beberapa dolina, dua atau lebih, bergabung menjadi satu membentuk ovala.

Topografi jalur Baron-Wonosari dapat dibagi dua, bagian selatan dari Baron Mulo merupakan daerah perbukitan dan bagian utara dari Desa Mulo-sekitar Wonosari adalah dataran karst. Tanahtanah di atas batuan karbonat di kawasan topografi karst didominasi golongan tanahtanah merah, sedangkan bagian utara terdiri atas golongan tanah-tanah hitam dan tanah merah. Ketebalan tanah di dolin bervariasi, ke arah tengah dolin meningkat, yang dapat mencapai $>5 \mathrm{~m}$, sedangkan di perbukitan (puncak dan lereng) berjeluk relatif tipis, $<30 \mathrm{~cm}$. Arah selatan-utara
Jalur Baron-Wonosari mempunyai perbedaan morfologi dan litofasies yang memunculkan keragaman warna tanah. Tulisan ini mencoba mencari hubungan antara morfologi dan kesarangan (porositas) batuan dengan warna tanah di atasnya. Penelitian dilakukan di sepanjang jalur Wonosari-Baron, Kabupaten Gunung Kidul, Propinsi Daerah Istimewa Yogyakarta (Gambar 1).

Sebagaimana dikatakan oleh Grim (1969) bahwa topografi menentukan ada tidaknya pergerakan air secara aktif melalui bahan lapukan. Disamping perannya sebagai pengontrol gerakan air tanah secara cacak (vertica), topografi juga memengaruhi proses pelindian serta erosi permukaan sehingga sangat menentukan laju penghilangan hasilhasil pelapukan. Bahan induk khususnya struktur dan kesarangannya diduga sangat

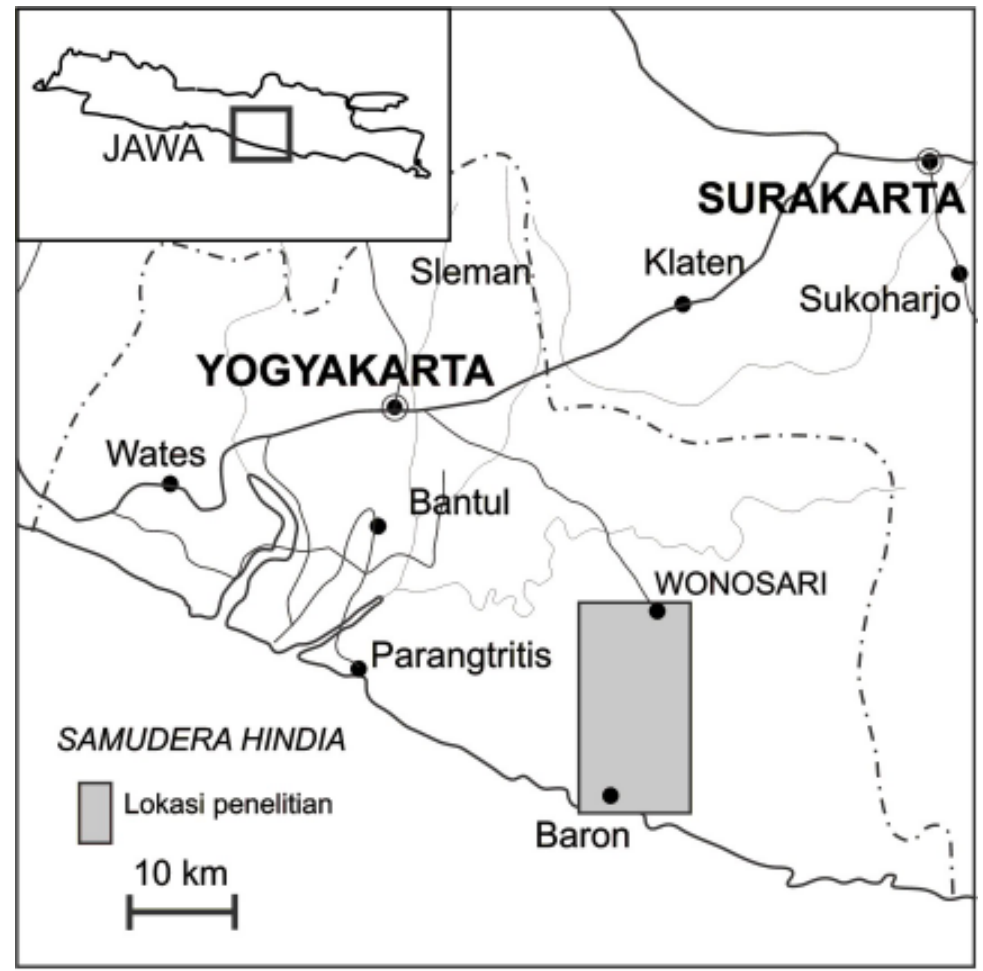

Sumber: Peta Geologi Lembar Surakarta-Giritontro, Jawa, Skala 1 : 100.000

Gambar 1. Peta Lokasi Daerah Penelitian 
mempengaruhi gerakan air secara vertikal. Topografi dan sifat-sifat batuan tersebut akan mempengaruhi efektivitas pelindian dan pembentukan tanah. Menurut Sartohadi dan Purwaningsih (2004) warna tanah merupakan sifat tanah yang mudah berubah oleh kondisi setempat seperti kondisi drainase tanah.

\section{METODE PENELITIAN}

Metode yang digunakan adalah pengamatan topografi dan batuan disertai dengan pemerian warna tanah sepanjang Jalur Wonosari - Baron. Pemerian warna menggunakan Munsell Soil Color Chart (USDA Handbook, 1975). Dalam tulisan ini golongan warna tanah dibagi menjadi dua golongan besar yakni: (1) golongan tanah-tanah merah dengan hue 2,5 YR5YR, dan (2). Golongan tanah-tanah hitam bue 10 YR dengan value dan chroma rendah (1-3) (Torrent dkk., 1983). Pengukuran kesarangan batuan dilakukan di Laboratorium Petrografi STM Pembangunan Yogyakarta, sedangkan analisis geokimia di laboratorium PPTM Bandung yang diperiksa menggunakan AAS.

\section{HASIL DAN PEMBAHASAN}

\section{Pengaruh Topografi}

Pengamatan di lapangan menunjukkan bahwa tanah yang ditemukan pada bentuk topografi berbeda cenderung mempunyai warna yang berbeda pula. Hasil pengamatan warna tanah di lapangan dapat dilihat pada Tabel 1 berikut ini. Lokasi pengamatan di kawasan karst (BaronMulo) meliputi 10 lokasi (contoh 1 - 10), sedangkan di kawasan dataran karst (Mulo-Wonosari) meliputi 18 lokasi (contoh $11-28$ ), yang 5 lokasi (contoh 24 - 28) merupakan napal. Tanah pada kawasan karst Baron-Mulo, yang pada umumnya mempunyai topografi perbukitan kasar, mempunyai warna merah (Tabel 1, Gambar 2-3). Sedangkan di dataran karst didominasi golongan tanahtanah hitam. Bentuk timbulan yang berbeda di dataran karst nampaknya sangat berpengaruh terhadap pembentukan golongan warna tanah. Namun demikian di tujuh lokasi pada dataran ini juga ditemukan tanah berwarna merah. Hal ini boleh jadi lebih disebabkan topografi di sekitar ke tujuh lokasi tersebut yang berombak sampai bergelombang (Tabel 1). Fakta tersebut di atas menunjukkan bahwa topografi dan morfologi sekitar lokasi keterdapatan tanah mempengaruhi keragaman warna tanah.

\section{Batuan Induk dan Kesarangan}

Pada jalur Baron-Wonosari, batuan yang berfungsi sebagai alas tanah, adalah batuan karbonat bagian dari Formasi Wonosari dan Formasi Kepek (Gambar 4). Batuan induk ini sangat mempengaruhi tampilan morfologi dari daerah penelitian. Hal ini disebabkan susunan batuan yang berbeda, sehingga menimbulkan perbedaan resistensi batuan terhadap pelapukan dan erosi. Bagian utara, yang merupakan dataran Wonosari, dibentuk oleh Formasi Kepek, sedangkan bagian selatan yang membentuk perbukitan karst disusun oleh Formasi Wonosari. Seperti banyak penulis (contohnya Ismoyowati dan Sumarso, 1975; Surono dkk., 1992; Samodra dan Sutisna, 1997; Sudarno, 1997; Rahardjo, 2007) utarakan bahwa Formasi Wonosari menjemari dengan Formasi Kepek (Gambar 5).

Formasi Wonosari terdiri atas batugamping dengan sisipan napal, batugamping napalan, batugamping tufan, batugamping konglomeratan dan batupasir tufan. Umur formasi ini ditentukan 
Tabel 1. Hubungan Warna Tanah dan Topografi Keterdapatannya Jalur Baron - Wonosari

\begin{tabular}{|c|c|c|c|c|c|c|}
\hline No. & Contoh & $\begin{array}{c}\text { Batuan } \\
\text { Alas } \\
\end{array}$ & $\begin{array}{l}\text { Ordo } \\
\text { tanah }\end{array}$ & $\begin{array}{l}\text { Warna } \\
\text { Tanah } \\
\end{array}$ & $\begin{array}{c}\text { Golongan } \\
\text { Warna } \\
\end{array}$ & Topografi \\
\hline & \multicolumn{6}{|c|}{ Lokasi Contoh di Kawasan Karst } \\
\hline 1. & KBD & Batugamping karst* & Alfisol & $2,5 \mathrm{YR} 3 / 4$ & Merah & Dolin \\
\hline 2. & BKM2 & Batugamping karst* & Alfisol & $5 Y R 3 / 3$ & Merah & Dolin \\
\hline 3. & BKM9 & Batugamping karst* & Alfisol & $5 Y R 3 / 4$ & Merah & Dolin \\
\hline 4. & BKM13 & Batugamping karst* & Alfisol & $2,5 Y R 3 / 4$ & Merah & Dolin \\
\hline 5. & CDM1A & Wackestone & Etisol & $7,5 Y R 4 / 2$ & Merah-coklat & Puncak bukit \\
\hline 6. & CDM1 & Grainstone & Alfisol & $5 Y R 3 / 4-4 / 6$ & Merah & Dolina \\
\hline 7. & $\mathrm{CDM} 3$ & Boundstone & Alfisol & $5 \mathrm{YR} 3 / 4$ & Merah & Dolina \\
\hline 8. & CDM5T & Boundstone & Inceptisol & $5 \mathrm{YR} 2 / 3-5 \mathrm{YR} 3 / 3$ & Merah & Kaki bukit \\
\hline \multirow[t]{2}{*}{9.} & CDM5 & Boundstone & Alfisol & $5 Y R 4 / 6-2,5 Y R 3 / 6$ & Merah & Dolina \\
\hline & \multicolumn{6}{|c|}{ Lokasi Contoh di Perbatasan Karst-Dataran Karst } \\
\hline \multirow[t]{2}{*}{10.} & $\mathrm{KA}$ & Mudstone & Alfisol & 2,5YR4/6 & Merah & Dataran karst \\
\hline & \multicolumn{6}{|c|}{ Lokasi Contoh Batugamping Berlapis di Dataran Karst } \\
\hline 11. & LNDM & Wackestone & Alfisol & $2,5 Y R 3 / 4-3 / 6$ & Merah & Berombak \\
\hline 12. & SPST & Batugamping berlapis* & Entisol & $2,5 Y R 3 / 4$ & Merah & Puncak bukit \\
\hline 13. & SDM4 & Batugamping berlapis* & Alfisol & $5 \mathrm{YR} 3 / 4$ & Merah & Berombak \\
\hline 14. & PDM2 & Batugamping berlapis* & Alfisol & $5 Y R 3 / 4$ & Merah & Berombak \\
\hline 15. & ADM1 & Wackestone & Alfisol & 5YR4/6-2,5YR3/4 & Merah & Bergelombang \\
\hline 16. & ADM2 & Wackestone & Alfisol & 5YR4/6-2,5YR3/4 & Merah & Bergelombang \\
\hline 17. & BDM1 & Wackestone & Vertisol & $10 \mathrm{YR} 3 / 1$ & Hitam & Dataran \\
\hline 18. & BDM3 & Batugamping berlapis* & Vertisol & $10 \mathrm{YR} 4 / 4$ & Hitam & Dataran \\
\hline 20. & BDM5 & Packstone & Vertisol & $10 \mathrm{YR} 2 / 1$ & Hitam & Dataran \\
\hline 21. & ML & Packstone & Vertisol & $10 \mathrm{YR} 3 / 1$ & Hitam & Basin \\
\hline 22. & SPUT & Batugamping berlapis* & Vertisol & 10YR3/1 & Hitam & Dataran \\
\hline \multirow[t]{2}{*}{23.} & SDM3 & Batugamping berlapis* & Vertisol & 10YR2/1 & Hitam & Basin \\
\hline & \multicolumn{6}{|c|}{ Lokasi Contoh Napal di Dataran Karst } \\
\hline 24. & $\mathrm{KP}$ & Wackestone & Vertisol & $10 \mathrm{YR} 3 / 1$ & Hitam & Dataran \\
\hline 25. & BDM2 & Wackestone & Vertisol & $10 \mathrm{YR} 3 / 1-4 / 2$ & Hitam & Dataran \\
\hline 26. & BDM6 & Wackestone & Vertisol & $10 \mathrm{YR} 3 / 1$ & Hitam & Dataran \\
\hline 27. & BDM7 & Wackestone & Vertisol & $10 \mathrm{YR} 3 / 1$ & Hitam & Dataran \\
\hline 28. & BDM8 & Wackestone & Vertisol & $10 \mathrm{YR} 3 / 1$ & Hitam & Dataran \\
\hline
\end{tabular}

Catatan: KA, ML, KP (Uca, 2002) ; tanah-tanah merah (5YR- 2,5YR); tanah-tanah hitam (10YR) SPST, SPUT (Murti, 2005)

$*$ : tanpa petrografi

Sumber: Hasil Analisis 


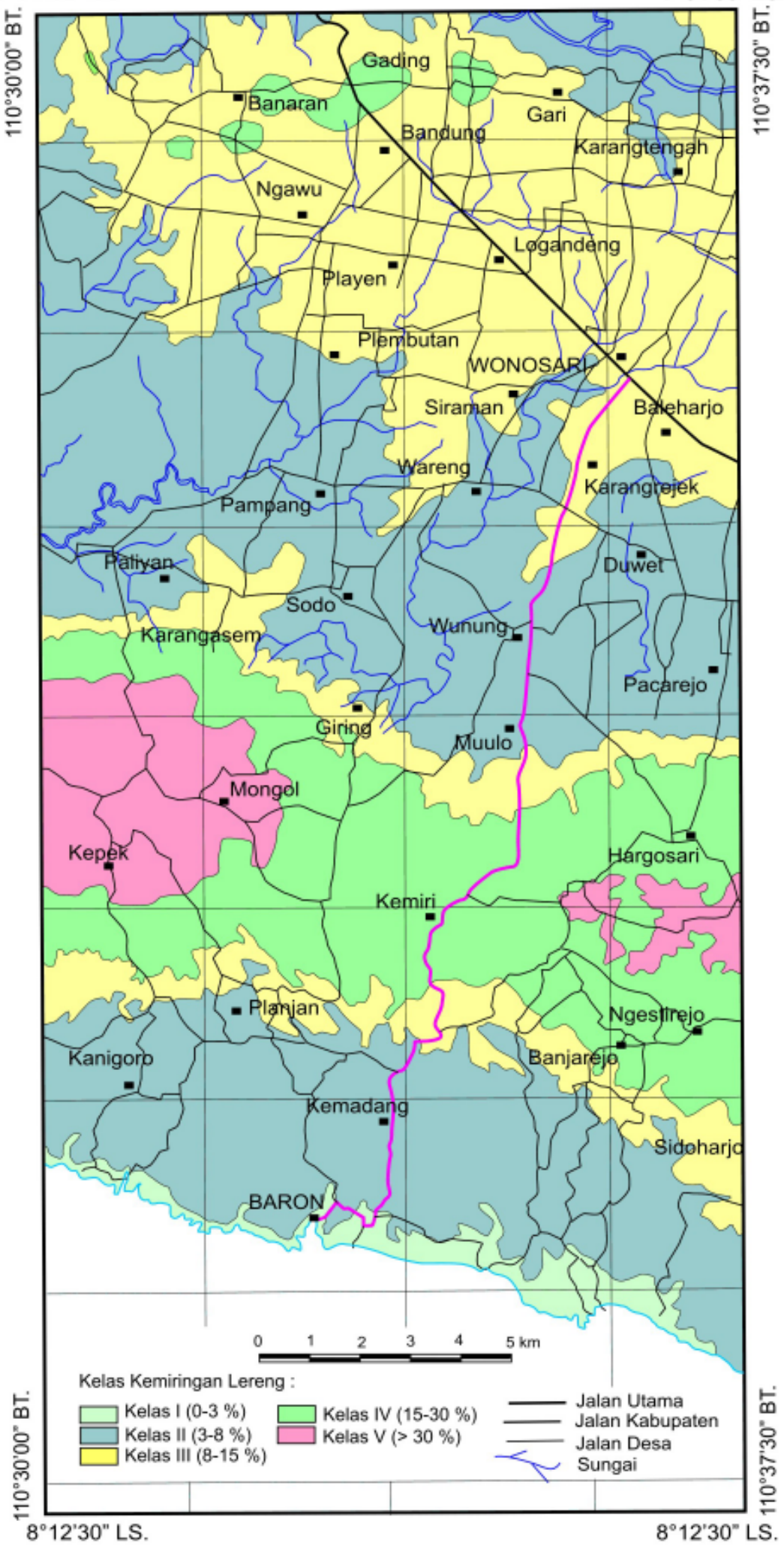

Sumber: Hasil Analisis

Gambar 2. Peta Pembagian Kemiringan Lereng Jalur Baron - Wonosari dan Daerah Sekitarnya 


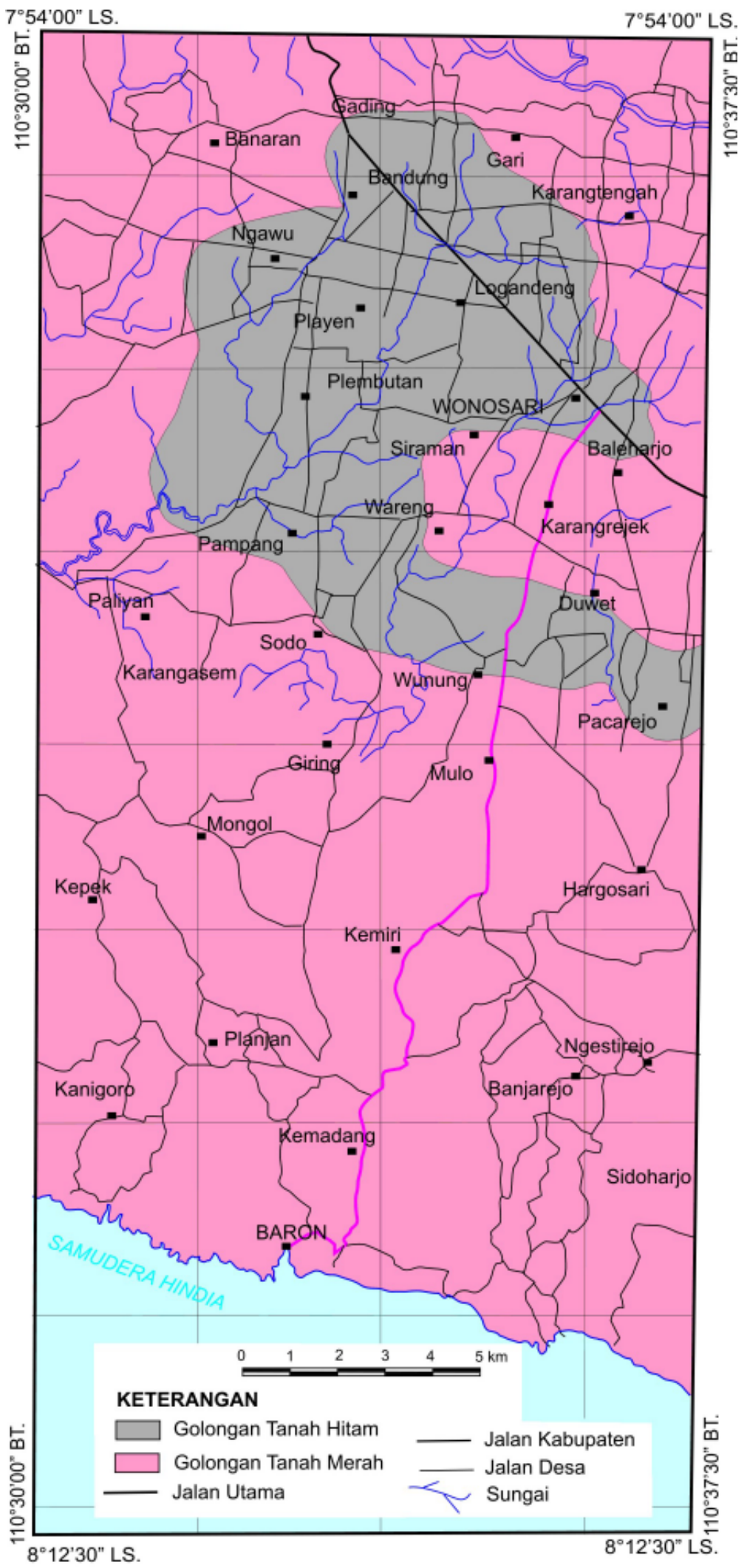

Sumber: Hasil Analisis

Gambar 3. Warna Tanah di Jalur Baron - Wonosari dan Daerah Sekitarnya 


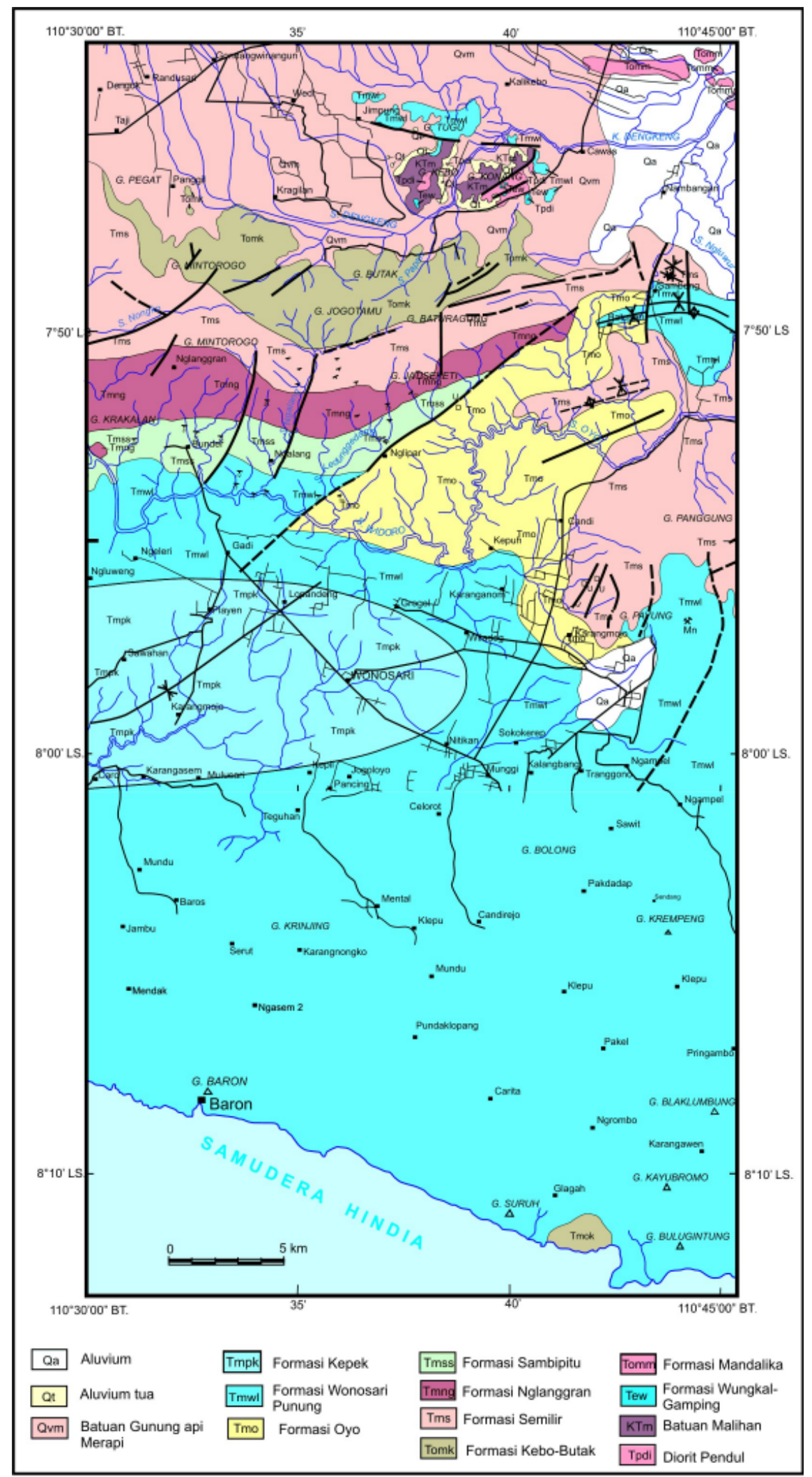

Sumber: Surono, dkk., 1992

Gambar 4. Peta Geologi Daerah Wonosari 


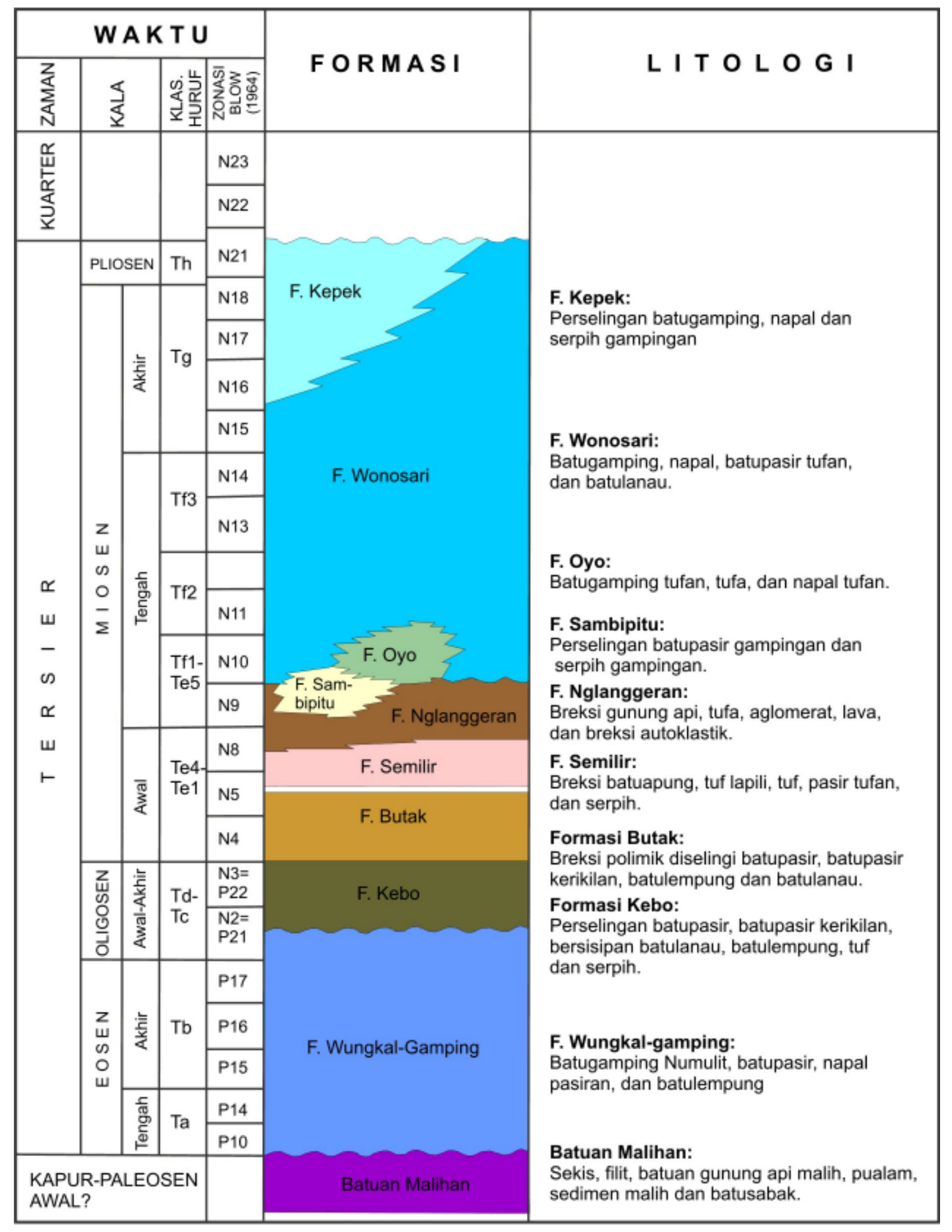

Sumber: Hasil Analisis

Gambar 5. Stratigrafi Daerah Wonosari dan Sekitarnya 
berdasarkan kandungan fosil foraminifera, berumur Miosen Tengah-Pliosen (Surono dkk., 1992; Sudarno 1997). Batugamping tersebut berupa mudstone, wakestone, packstone dan grainstone di bagian utara, dan ke selatan boundstone lebih berkembang. Pada umumnya formasi ini berlapis baik. Ketebalan lapisan berkisar beberapa $\mathrm{cm}$ sampai beberapa $m$ di bagian utara, terutama pada dataran Wonosari, sedangkan ke arah selatan menebal. Pada bagian selatan jalur Wonosari-Baron, Formasi Wonosari ini membentuk morfologi perbukitan karst. Hal ini disebabkan pada bagian ini batugamping yang banyak berkembang di kawasan ini adalah boundstone dengan ketebalan setengah sampai beberapa meter. Ini tentu mengakibatkan resistensi batuan terhadap pelapukan lebih tinggi dibandingkan di bagian utara yang didominasi batugamping berlapis. Perbedaan batuan penyusun di kedua kawasan tersebut di atas diduga juga dapat mempengaruhi kesarangan batuan.

Formasi Kepek terdiri atas napal dengan sisipan batugamping berlapis. Ketebalan formasi ini lebih kurang $200 \mathrm{~m}$ (Surono dkk., 1992), namun di tepi cekungannya jauh lebih tipis. Karena tipisnya ketebalan Formasi Kepek ini menyebabkan bentuk morfologinya banyak dipengaruhi resistensi batuan pembentuk Formasi Wonosari yang berada di bawahnya. Pada citra satelit ASTER, Formasi Kepek ini membentuk morfologi dataran Wonosari.

Tabel 2 adalah hasil pengukuran kesarangan mikro batuan dan warna tanah di lokasi yang sama. Hanya ada dua pengukuran pada kawasan karst Baron-Mulo,

Tabel 2. Kesarangan mikro pada contoh batuan jalur Baron-Wonosari

\begin{tabular}{lccc}
\hline \hline Nomor Contoh & Litologi & Kesarangan (\%) & $\begin{array}{c}\text { Golongan wa } \\
\text { Tanah }\end{array}$ \\
\hline \multicolumn{2}{l}{ Kawasan perbukitan karst Muulo-Baron } & & merah \\
\hline 1. CDM1 & Grainstone & 11,80 & merah \\
2. CDM5 & Boundstone & 3,80 &
\end{tabular}

\section{Kawasan dataran Wonosari}

\begin{tabular}{llcl}
\hline 1. KA & Mudstone & 12 & merah \\
2. ADM1 & Wackestone & 12,55 & merah \\
3. SPST & Batugamping berlapis* & 20,2 & merah \\
4. SPUT & Batugamping berlapis* & 19,9 & hitam \\
5. KP & Wackestone & 16 & hitam \\
6. BDM6/R & Wackestone & 16,14 & hitam \\
7. BDM7/R & Wackestone & 42,37 & hitam \\
8. ML & Packstone & 6 & hitam \\
\hline
\end{tabular}

* tidak dilakukan analisa petrografi

Sumber: Hasil Analisis 
keduanya menunjukkan warna merah walaupun salah satunya mempunyai kesarangannya kecil, hanya 3,80\%. Apabila kedua contoh ini dapat mewakili kawasan ini, berarti sangat mungkin warna tanah tersebut lebih dipengaruhi topografinya (lihat Tabel 1). Atau kemungkinan lain disebabkan adanya kesarangan makro dan mega pada batuan boundstone, yang mendominasi kawasan tersebut, yang mempunyai kesarangan relatif lebih besar dibandingkan kesarangan batuan pada kawasan dataran Wonosari, seperti yang telah diukur oleh Kusumayuda (2000, lihat Tabel 3).

Pengukuran kesarangan batuan pada 8 lokasi yang berbeda di dataran Wonosari menunjukkan adanya keragaman kesarangan mikro batuan di kawasan ini. Hampir semua hasil pengukuran kesarangan di kawasan ini mempunyai nilai lebih tinggi dibandingkan dua hasil pengukuran di kawasan karst Baron-Mulo. Hanya satu pengukuran yang menjukkan nilai rendah (ML). Tabel 2 menunjukkan bahwa tidak adanya hubungan antara litologi, kesarangan mikro dan warna tanah. Nilai kesarangan terbesar $42,37 \%$ di lokasi $\mathrm{BDM} 7 / \mathrm{R}$ justru mempunyai warna tanah hitam. Kiranya perlu diperhatikan juga keragaman batuan yang membentuk morfologi dataran Wonosari yakni Formasi
Kepek, yang terdiri dari perselingan napal dan batugamping berlapis (Surono dkk., 1992; Rahardjo dkk., 1992; Sudarno, 1997). Hal ini tentu sangat mempengaruhi kelulusan air di kawasan ini. Napal yang berbutir halus dan relatif kedap air bila mengalasi batugamping akan menurunkan secara signifikan kelulusan airnya. Hasil analisis napal Wonosari oleh Mulyanto dan Virgawati (2006) menunjukkan adanya smektit $\pm 20 \%$. Mineral tersebut dalam kondisi lembab dapat mengembang dan menutup pori-pori batuan sehingga menurunkan daya lulusnya. Dari fakta tersebut (Tabel 2) dapat dikatakan bahwa kesarangan mikro batuan tidak berpengaruh terhadap pembentukan tanahtanah merah.

Tabel 3 menunjukkan bahwa nilai kesarangan baik fasies Wackstone, Packstone, maupun Boundstone mempunyai kisaran yang cukup lebar. Diduga bahwa kesarangan makro dan mega di wilayah utara yang didominasi Wackstone kurang berkembang, sebaliknya di kawasan selatan yakni daerah karst berkembang dengan baik. Hal tersebut sejalan dengan pengamatan lapangan bahwa di kawasan karst banyak dijumpai rekahan-rekahan batugamping. Mulyanto dkk. (2005) juga mengatakan bahwa rekahan-rekahan

Tabel 3. Kisaran Kesarangan Batu Gamping Gunungsewu

\begin{tabular}{lccc}
\hline \hline \multirow{1}{*}{ Fasies } & \multicolumn{3}{c}{ Kesarangan (\%) } \\
\cline { 2 - 4 } & Mikro & Makro & Mega \\
\hline Wackstone & $4,93-27,91$ & $4,50-18,00$ & $3,00-17,00$ \\
Packstone & $3,75-21,90$ & $3,00-20,00$ & $5,00-20,00$ \\
Boundstone & $2,80-27,26$ & $3,00-17,50$ & $5,00-18,00$ \\
\hline
\end{tabular}

Sumber: Kusumayudha, 2000 
batugamping di kawasan karst Gunungsewu dapat mengarahkan genesis tanahtanah merah.

\section{Geokimia Batuan}

Komposisi kimia batuan karbonat Wonosari sangat bervariasi baik unsur penentu warna tanah seperti besi dan mangan maupun unsur-unsur yang lain. Tabel 4 menunjukkan bahwa kisaran konsentrasi baik unsur besi maupun Mn batuan sangat bervariasi baik di lingkungan tanah-tanah merah maupun tanah-tanah hitam.

Warna merah tanah disebabkan oleh oksida-oksida besi yang teroksidasi dengan baik, sedangkan warna hitam oleh oksidaoksida mangan dan bahan organik yang terhumifikasi, sebagaimana dikatakan oleh Torrent dkk (1983), Notohadikusumo (2000), dan Mulyanto dkk (2006). Tabel 4 di atas sangat menarik untuk dicermati yakni bahwa batuan-batuan yang mengandung unsur-unsur besi yang relatif tinggi seperti BDM 6, BDM 7, dan SPUT memunculkan warna tanah hitam, sedangkan CDM 5 dan KA yang mengandung besi relatif sedikit justru memunculkan tanah-tanah merah. Hal ini juga menunjukkan bahwa gejala kewarnaan tanah di atas batuan karbonat tidak dipengaruhi oleh komposisi kimia khususnya kadar besi dan mangan batuan. Munculnya warna merah diduga oleh genesis tanah yang sangat terkait dengan intensitas pelindian yang sangat dipengaruhi oleh kesarangan batuan terutama kesarangan makro sebagai kesarangan sekunder batuan. Pembentukan warna merah tersebut dapat dijelaskan melalui deret mobilitas ion yang dikemukakan oleh Hudson (1995) dengan urutan yang menurun yakni $\mathrm{Cl}^{-}>\mathrm{SO}_{4}^{-2}>$ $\mathrm{Na}^{+}>\mathrm{Ca}+2>\mathrm{Mg}^{+2}>\mathrm{K}^{+}>\mathrm{SiO}_{4}>\mathrm{Fe}_{2} \mathrm{O}_{3}$
$>\mathrm{Al}_{2} \mathrm{O}_{3}$. Proses pelindian yang semakin intensif menyebabkan terlindinya basabasa dan Si hasil pelapukan serta meningkatnya konsentrasi besi dan aluminium secara relatif. Peningkatan konsentrasi besi dalam suasana bertata udara bagus menyebabkan terbentuknya persenyawaan besi dalam bentuk ferri yang menimbulkan warna merah pada tanah. Warna merah dari senyawa-senyawa besi disebabkan oleh tingkat hidrasi yang rendah, sedangkan yang kuning menunjukkan tingkat hidrasi yang lebih tinggi.

Pada uraian sebelumnya menunjukkan fakta bahwa warna tanah berhubungan dengan topografi sekitarnya (Tabel 1). Tanah yang dijumpai pada topografi kasar mempunyai warna merah, sebaliknya tanah di atas dataran berwarna hitam. Pada umumnya air permukaan yang mengalir pada topografi kasar mempunyai kecepatan aliran lebih cepat dibandingkan di tempat yang datar. Aliran yang cepat tentu mempunyai kemampuan pelindian lebih kuat dibandingkan yang lemah. Hal tersebut akan berdampak pada pemiskinan ion-ion yang mempunyai indeks keterlarutan tinggi seperti $\mathrm{Na}, \mathrm{Ca}, \mathrm{Mg}$, dan $\mathrm{K}$ dan peningkatan secara relatif Fe. Indeks keterlarutan Mn lebih tinggi dibandingkan Fe sehingga mobilitasnya lebih tinggi. Sifat tersebut menyebabkan konsentrasi Mn tanah dalam lingkungan yang mempunyai daya pelindian tinggi lebih rendah dibanding yang berpelindian lemah. Dengan kata lain bahwa lingkungan yang berpelindian lemah menyebabkan konsentrasi Mn tanah lebih tinggi dan cenderung menimbulkan warna hitam tanah. Peningkatan Fe dalam tanah bila dialasi oleh batuan yang mempunyai kesarangan makro tinggi atau timbulan yang relatif kasar akan mempunyai tata udara yang relatif lebih bagus dan menimbulkan warna merah. Sebaliknya 


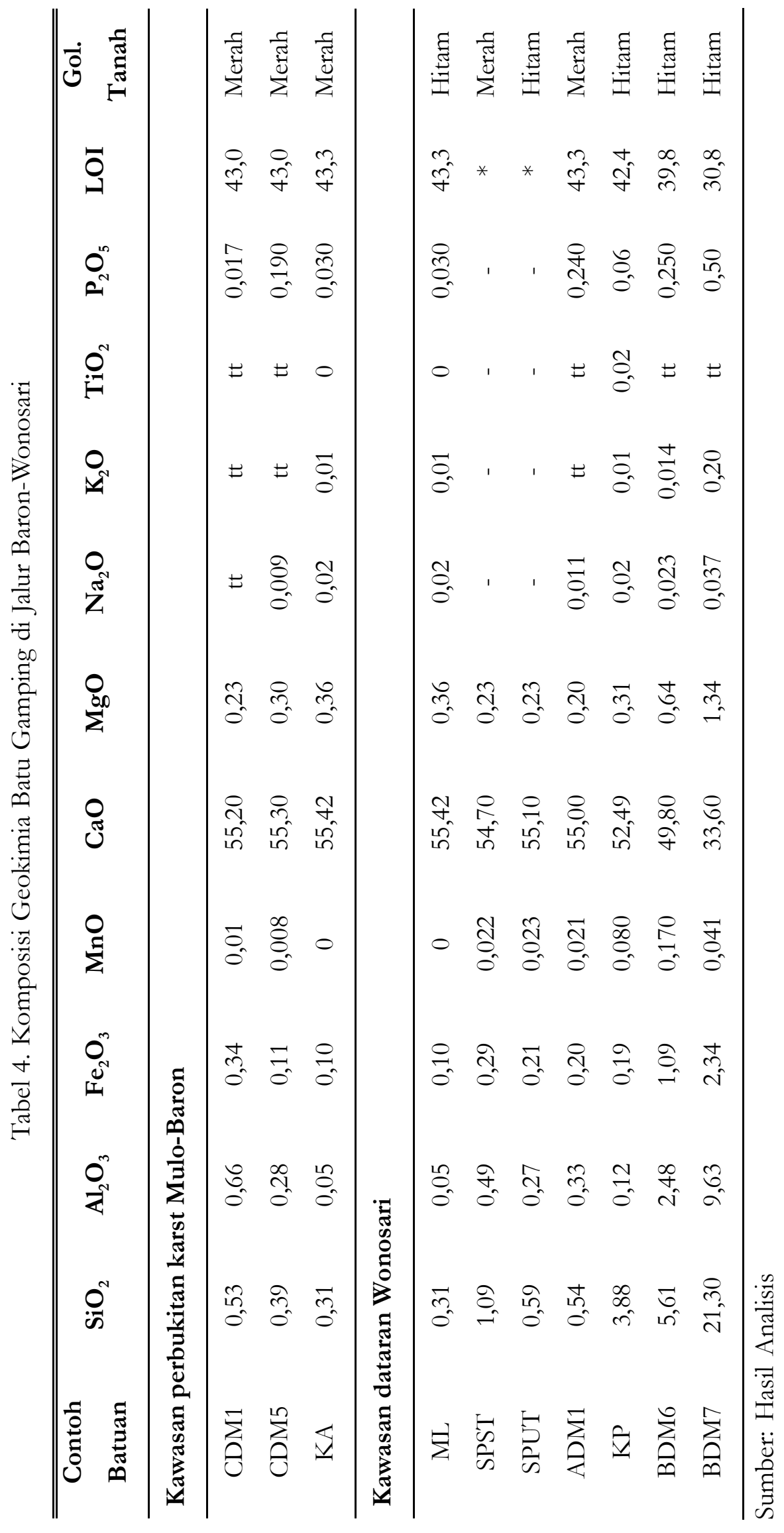


pada dataran, seperti dataran Wonosari, yang mempunyai kemiringan landai, aliran air akan lambat sehingga daya pelindiannya rendah. Suasana dalam tanah menjadi lebih reduktif atau bertata udara relatif lebih buruk sehingga tidak memunculkan warna merah.

Sebaran golongan tanah-tanah yang berkembang di kawasan karst khususnya bagian dolin semuanya adalah tanah-tanah merah. Hal tersebut cukup menarik untuk dicermati. Bila hanya melihat morfologi dolin yang berbentuk cekungan/ basin seharusnya merupakan tempat akumulasi bahan-bahan hasil pelapukan dan proses pelindiannya yang sangat terhambat sehingga tidak banyak mengalami kehilangan ion-ion hasil pelapukan seperti $\mathrm{Ca}, \mathrm{Na}, \mathrm{K}, \mathrm{Mg}$, Mn dan Si. Proses demikian seharusnya akan terbentuk lempung tipe 2:1 khususnya montmorillonite dan membentuk tanah Vertisol yang berwarna hitam karena akumulasi Mn sebagaimana dikemukakan oleh banyak peneliti antara lain Wambeke (1992) dan Wilding dkk. (1983). Secara alamiah tentu ada faktor yang mengarahkan terbentuknya tanahtanah merah di kawasan tersebut. Hasil penelitian Kusumayudha (2000) menunjukkan bahwa batuan karbonat di kawasan Gunungsewu selain mempunyai pori mikro (kesarangan primer), juga mempunyai pori makro dan mega yang merupakan kesarangan sekunder setelah mengalami karstifikasi. Batuan yang terkarstifikasi mempunyai daya kelulusan yang dapat mencapai 1000 kali dibandingkan yang belum terkarstifikasi Acworth (2001) (dalam Aji dkk, 2005). Kesarangan sekunder, yang umumnya berupa retakan dan kekar, tersebut diduga yang berperan kuat dalam mengarahkan terbentuknya tanah-tanah merah di kawasan karst Gunungsewu.

\section{KESIMPULAN}

1. Relief topografi adalah salah satu faktor yang mempengaruhi warna tanah. Topografi yang mempunyai relief kasar cenderung membentuk tanah merah, sedangkan topografi yang datar akan membentuk tanah hitam.

2. Kesarangan mikro (primer) batuan tidak mempengaruhi warna tanah, tetapi kesarangan sekunder diduga sebagai pengontol terbentuknya golongan tanah-tanah merah.

3. Gejala kewarnaan tanah tidak dipengaruhi oleh kadar besi dan mangan batuan. Namun sangat dipengaruhi kondisi lingkungan pelapukan. Lingkungan yang berpelindian bagus cenderung mengarahkan terbentuknya golongan tanah-tanah merah, sebaliknya yang berpelindian buruk mengarahkan terbentuknya golongan tanah-tanah hitam.

\section{DAFTAR PUSTAKA}

Aji, T.N.. dan Eko Haryono. 2005. Hidrology Karst. Potensi dan Tantangan untuk Pengembangan Pertanian. Seminar Sehari Jurusan Ilmu Tanah, Fak. Pertanian UGM. Tanggal 18 Juni 2005

Grim, R.E. 1968. Clay Mineralogy. McGraw-Hill Book Company. New York, St. Louis, San Francisco, Toronto, London, Sydney, 596 p. 
Hudson, B.D. 1995. Reassesment of Polinov's Ion Mobility Series. Soil Sci.Soc.Am.J. 59:11011103.

Husein, S. dan Sriyono, 2007. Tinjauan Geomorfologi Pegunungan Selatan DIY/Jawa Tengah: Telaah Peran Faktor Endogenik dan Eksogenik dalam Proses Pembentukan Pegunungan. Prosiding Workshop: Potensi geologi Pegunungan Selatan dalam pengembangan wilayah, Hotel Inna Garuda, Yogyakarta, 27-29 November 2007.

Ismoyowati, T. \& Sumarso, 1975, Contribution to the Stratigraphy of the Jiwo Hills and Their Southern Surroundings (Central Java), Proceedings Indonesian Petroleum Association Fourth Annual Convention Vol. 2: 19-26

Kusumayudha, S.B. 2000. Kuantifikasi Sistem Hidrogeologi dan Potensi Airtanah Daerah Gunungsewu, Pegunungan Selatan, DIY (Didekati dengan Analisis Geometri Fraktal). Disertasi Doktor ITB.

Mulyanto, D., T. Notohadikusumo, dan B.H. Sunarminto. 2005. Peran Porositas Sekunder Batugamping terhadap Pembentukan Tanah-Tanah Merah di Kawasan Karst Gunungsewu. Agrin Vol. 9 (2): 101 - 109.

Mulyanto, D. dan Virgawati, S. 2006. Genesis Vertisol di Atas Napal Daerah Wonosari. Jurnal Tanah dan Air Vol. 7 (1): 46-56.

Mulyanto, D., T. Notohadikusumo, dan B.H. Sunarminto. 2006. Hubungan Tingkat Pemerahan Tanah di Atas Batuan Karbonat dengan Komponen-Komponen Pembentuknya. Jurnal Ilmiah Habitat Vol. 17 (3): 235 - 245.

Murti, D.A. 2005. Genesis Tanah di Atas Batuan Karbonat di Dusun Serpeng Kidul Desa Pacarejo Kecamatan Semanu Kabupaten Gunungkidul. Skripsi S1 Jurusan Ilmu Tanah, Faperta UPNVY.

Notohadiprawiro, T. 2000. Tanah dan Lingkungan. Pusat Studi Sumber Daya Lahan UGM, 187 hal.

Surono, Toha, B. \& Sudarno, I, 1992. Peta Geologi Lembar Surakarta-Giritontro, Jawa, Skala 1 : 100.000. Pusat Penelitian dan Pengembangan Geologi, Bandung.

Sartohadi, J. \& Purwaningsih, R.. 2004. Korelasi Spatial antara Tingkat Perkembangan Tanah dengan Tingkat Kerawanan Gerak Massa di DAS Kayangan Kabupaten Kulon Progo Daerah Istimewa Yogyakarta. Forum Geografi. Vol. 18(1) Juli 2004: 27.

Sudarno, 1997. Kendali Tektonik terhadap Pembentukan Struktur pada Batuan Paleogen dan Neogen di Pegunungan Selatan, Daerah Istimewa Yogyakarta dan sekitarnya. Thesis Magister Teknik, Institut Teknologi Bandung, Bandung, 167p (tidak diterbitkan).

Sumarso \& Ismoyowati, T., 1975. A Contribution to the Stratigraphy of the Jiwo Hills and Their Southern Suroundings. Proceeding of 4th Annual Convention of Indonesia Petroleum Association, Jakarta. 
Rahardjo, W., 2007. Foraminiferal Biostratigraphy of Southern Mountains Tertiary Rocks, Yogyakarta Special Province. Prosiding "Potensi geologi Pegunungan Selatan dalam Pengembangan Wilayab", Yogyakarta 27-29 November 2007.

Samodra, H. dan Sutisna, K. 1997. Peta Geologi Lembar Klaten (Bayat), Jawa, skala 1 : 50.000. Pusat Penelitian dan Pengembangan Geologi.

Torrent, J., Schwertmann, U., Fechter, H., and Alferez, F., 1983. Quantitative Relationship between Soil Color and Hematite Content. Soil Science 136, 6, pp. 354-359.

Uca, 2001. Karakterisasi Tanah pada Litosekuen Bentanglahan Karst di Kecamatan Tepus, Gunung Kidul. Tesis S-2 Program Pasca Sarjana UGM.

Wambeke, A.V., 1992. Soil of the Tropics. Properties and Appraisal. McGrawHill, Inc. New York.

Wilding, L.P., Smeck, N.E. and Hall, G.F., 1983. Pedogenesis and Soil Taxonomy. I. Concepts and Interactions. Elsevier. Amsterdam, Oxford, New York. 